\title{
Differentiating Cooperative Learning and Collaborative Learning: What Is Fit for Pakistani Higher Education?
}

\author{
Abdul Hameed Panhwar ${ }^{1}$, Abdul Sattar Gopang ${ }^{2}$, Zubair Ahmed Chachar ${ }^{2} \&$ Shahnaz Baloch $^{3}$ \\ ${ }^{1}$ Institute of English Language and Literature, University of Sindh Jamshoro, Pakistan \\ ${ }^{2}$ Faculty of Education, University of Sindh Jamshoro, Pakistan \\ ${ }^{3}$ Karachi University Business School, University of Karachi, Pakistan \\ Correspondence: Abdul Hameed Panhwar, Institute of English Language and Literature, University of Sindh \\ Jamshoro, Pakistan. E-mail: hameed.panhwar@usindh.edu.pk
}

Received: April 19, 2017 Accepted: May 9, 2017 Online Published: July 26, 2017

doi:10.5539/ijel.v7n5p119 URL: http://doi.org/10.5539/ijel.v7n5p119

\begin{abstract}
This paper attempts to clarify the relationship between cooperative and collaborative learning and shows that cooperative learning could be more effective in the context of Pakistani higher education. It is argued that although both these approaches are forms of group work, cooperative learning is more structured and controlled. Collaborative learning, on the contrary, is not that structured and depends on students to work independently in groups without involving the instructor authority very much. Therefore, the researchers in this research paper tend to justify how the teaching of English as a second language (ESL) in Pakistani higher education is more or less teacher-cantered and exam-based and how a structured approach to group work like cooperative learning might be of a great assistance in teaching English language in Pakistani universities and colleges. Hence, the study, through the critical review of the studies on cooperative and collaborative learning, aims at providing the rationale that cooperative learning might be more effective in teaching ESL classes in the present context. Furthermore, with the help of the previous research, Pakistani teachers and educators are provided with useful methods and suggestions for how to use cooperative learning in their ESL classes effectively. Thus, the aim of the paper is to offer additional understanding on how instructors can efficiently adopt cooperative learning to ESL teaching-learning processes in their classrooms.
\end{abstract}

Keywords: cooperative, collaborative, higher education, structured, ESL

\section{Introduction}

Both collaborative learning and cooperative learning are forms of group work. These both support small-group active student engagement over inactive, lecture-oriented teaching and require specific tasks to be accomplished. Each of them intrinsically uses discovery-based methods to learning. Laal \& Laal (2012) use collaborative learning interchangeably with cooperative learning and very bravely associate five elements of cooperative learning with collaborative learning. It is strange, why the name is interchangeably used when the very they bear two names. Although both of them assign various group roles, collaborative learning could have fewer roles assigned. Thus, cooperative learning is generally more structurally defined than collaborative learning (Cooper \& Robinson, 2002; Rockwood, 1995, 1995).

Hence, the paper further examines the differences between cooperative and collaborative learning and attempts to justify how cooperative learning can be more effective in the context of Pakistani higher education. Since cooperative leaning is a very structured approach to group work, its structured nature might be used as assistance to the situation. Due to large size of classes and exam-based curricula, more loose approaches to group work such as collaborative learning may lead to disturbing situations in Pakistani context. To analyse cooperative learning being more effective in ESL classes in the context of Pakistan than collaborative learning, firstly, the contextual issues of English language teaching and learning have been explored through a brief but relevant literature review, and secondly, critical review of the available literature and arguments on these approaches has been conducted. These reviews aim to establish the ground for how cooperative learning may more effectively be adopted in Pakistan especially in ESL classes of higher education than other forms of group work such as collaborative learning. 


\section{Analysis of the Context}

\subsection{English Language Teaching and Learning in Pakistan}

English, being the language of power in comparison with Urdu (national language of Pakistan) and other local languages of Pakistan, enjoys its status as the language of the elite class (consisting of 10-20\%) of the whole population (Rassool \& Mansoor, 2009; Shamim, 2011). Thus, English in Pakistan happens to be the language of all branches of knowledge from art to business. Furthermore, it has been introduced as a compulsory subject from class one to graduate classes (Ahmad et al., 2011). Although English language has been used as a lingua franca since the independence of Pakistan, the conditions for English language teaching and learning in Pakistan are not favourable. It is used as a language of offices and education specifically in the context of science and technology. Despite the fact that English is taught as a compulsory subject from class first, students, particularly, from rural areas, cannot communicate in English easily. They feel deficient in all four language skills. The main reason behind this situation about teaching and learning in Pakistan is that the techniques used to teach English language are not communicatively up to the mark (Warsi, 2004). In spite of its being a second language of Pakistan (Warsi, 2004), the syllabi of English language in Pakistan do not meet the specific curricular goals. Teachers are not trained and are not armed with modern teaching equipment; the majority of teachers use outdated teaching methods and contextually irrelevant textbooks to teach English as a foreign or second language. Examinations to assess English Language proficiency is entirely flawed and does not include the modern efficient evaluation and assessment methods (Warsi, 2004).

Universities in Pakistan have achieved greater scope in terms of English teaching. Both private and public universities offer multiple courses of English (Rahman, 1999; Mansoor, 2003). The courses of English language are offered largely at the undergraduate level including some courses at the postgraduate level in particular departments, i.e. Business and public management sciences. These courses are conducted by the institutes of English in other departments and institutes in the general universities. These universities also hire visiting faculty to teach English compulsory and the permanent teachers are supposed to teach English Literature or Linguistics to the students of major subjects. A prescribed syllabus of English is taught to undergraduate students. In professional universities, the English language programme is controlled by the departments concerned or the faculty concerned. In the English language programmes of professional universities, teachers design the course for English themselves. The assessment and evaluation of the courses focuses on content and information (Shamim, 2011).

In spite of huge efforts into English language teaching reforms on the part of government, the results fall greatly short of expectations (Mansoor, 2003). The usual length of the English courses is 48 hours or one semester during the first year of their study programme. The use of modern educational equipment is very rare in these classes even if the equipment is available, students get very little time for the activities to express and participate in the class; therefore they very seldom develop their academic skills. The process of teaching and learning focuses chiefly on securing decent grades in the course-based examination. Regarding feedback, students are given no or very little feedback on their oral and written tasks. These practices limit the opportunities for learning English to achieve high level proficiency needed for higher education and professional jobs. Unsurprisingly, graduates are found to be inefficient and incompetent at their current level of English which has created dissatisfaction among employers and job seekers (Shamim, 2011). According to Shamim (2011), the main reasons may be many, but the most important reasons for the failure of English teaching in Pakistan may be the lack of proper teacher training and their formal qualification for English language teaching, insufficient research on English language teaching and learning and large classes.

\subsection{Large Classes in ELT}

In the context of Pakistani colleges and universities usually classes are very large of around more than a hundred students in a class. Large classes create so many constraints which make the process of teaching and learning English language difficult for teachers and students. For students the course content becomes useless and meaningless due to the large number of students in the class (Bughio, 2013). The teachers become unable to use appropriate and interactive teaching methods in such large classes, therefore they normally pass time instead of teaching properly and meeting the needs of students' interest and knowledge. The greatest number of the teachers of large classes agrees that large classes are a serious problem (Shamim, 1993). The students in these classes are mostly of multi-level and heterogeneous in regard to their mental abilities and socio-economic background; therefore, it becomes exceedingly problematic to gratify them with the help of outdated teaching techniques. The huge size of classes leaves no or tremendously little opportunity for teacher-student interaction. In such a large class, the teacher performs as an authoritative ruler rather than a facilitator (Raja, 2012). It is normally found by the 
researchers that the traditional lecture method of teaching curtails students' cognitive development (Raja, 2012). Therefore, there is a need of developing more appropriate teaching methodologies that may address large English language classes' problems more effectively.

The contextual overview of the situation suggests that specifically in higher education institutes of Pakistan, English language teaching and learning is not conducted through the methods which create communicative environment and engage students in the process of learning. The researchers, therefore, hypothesise that since the situation is very chaotic because it is swarmed with the problems arising from large classes and traditional teaching methods and outdated syllabus, unstructured type of group work such as collaborative learning may not be very effective. From our study of these two types group work i.e. collaborative learning and cooperative learning, we reach the conclusion that cooperative learning might address the issues of the context efficiently. Therefore, the following critical review would build the ground for our argument.

\section{Critical Review: Differentiating Cooperative and Collaborative Learning}

Despite the fact that many people think collaborative learning and cooperative learning are similar, they exactly are different. For example, those people who think that these are similar, they only consider team work in general. No doubt, they both are a type group work; they arguably differ. Collaborative learning is more intentional and wants teachers to structure or create their own activities; on the other hand, cooperative learning has already its well-organised techniques. Furthermore, some authors consider cooperative learning different on the traditional grounds. They believe that cooperative learning follows traditional line of instruction in which the teacher still maintains authority and students remain passive (Bruffee, 1995). Barkley, Cross, \& Major (2014) argue that collaborative learning has its base in social constructivism. It aims to make students and teachers work together in order to co-construct knowledge. It is a teaching-learning method that assumes that people make meaning when they work socially in collaboration (Matthews, 996). This point put forward very much associates collaborative learning with cooperative learning. Cooperative learning is also associated with social cultural theory by its proponents and considers learning as social process in which individuals discuss and co-construct the meaning (McCafferty, Jacobs, \& DaSilva Iddings, 2006).

Collaborative learning generally means students learning together in pairs or small groups to accomplish common learning goals. It is termed as cooperative and group/team learning (Barkley, Cross, \& Major, 2014). Barkley, Cross, \& Major (2014) categorise three main features of collaborative learning: intentional design, co-labouring and meaningful learning. According to the researchers, it follows intentional design because unlike group learning, it does not merely make students sit together and work; rather teachers structure intentional learning techniques for learners by either innovating already existent strategies or by creating their own activities. This point here contradicts with cooperative learning because cooperative learning contains already tested activities, teachers do not need to create their own techniques. However, they might necessarily innovate or adapt them (Johnson \& Johnson 2009). Co-labouring means that all learners in the group 'must engage actively in working together' towards the tasks objectives (Barkley, Cross, \& Major, 2014). This means all learners are required to contribute fairly equally on average. This element, however, matches one of the objectives of cooperative learning, but it is not clear how. In meaningful learning, all learners, by working in teams, must aim to improve their understanding of the subject matter. It is not clear whether learners care for others learning in the collaborative learning setting. In contrast, in the cooperative learning setting, all learners are not only responsible for enhancing their own learning, but also learning of their group peers (Johnson \& Johnson, 1989; Cohen, 994, Slavin, 1995; Johnson \& Johnson, 2009). Collaborative learning is not likely to promote the shifting of responsibilities to learners because according to Barkley, Cross, \& Major (2014), it renders the task meaningless if learners are not accomplishing the targeted learning goals. Collaborative learning rather focuses on co-labouring in which team-members work together to share the workload equally as they progress to the task accomplishment.

Rockwood $(1995,1995)$ separates these methods by the teacher's role. In cooperative learning, the teacher remains the central authority in the class, with group tasks commonly more closed-ended and sometimes having explicit answers. In contrast, in the collaborative learning setting, the teacher relinquishes his or her power and authorises the small groups who are repeatedly given more open-ended, multifaceted tasks. Rockwood suggests the use of both the approaches depending on the educational maturity of students. He supports the more structured cooperative learning style for foundational knowledge typified in gateway courses, and collaborative learning for higher level, less foundational knowledge content. Bruffee (1995), by distinguishing between these, argues that cooperative learning is a social process based on structured group work aiming to promote both social and academic achievement - learners acquire new social skills and learn the ways to work collaboratively in order to accomplish academic goals. These goals are achieved by imposing structure and control by the 
teacher. The teacher holds learners responsible for learning together. Thus, the teacher becomes like a director who adopts teaching strategies to promote social skills, cooperation, positive interdependence, and accountability (Brody, 1995). Bruffee argues that students in higher education should not depend on the teacher. Therefore, according to him in collaborative learning, the teacher should not perform as an authority to monitor group learning, but rather he should have responsibility to become a member of the students' community in search of knowledge. Bruffee, thus, further argues that the aim of cooperative learning is to make students work together in harmony and reciprocal support to find the solution, whereas the objective of collaborative learning is to develop independent, expressive, rational people, even if at times such an objective encourages opposition and competition that appears to challenge the principles of cooperative learning. Thus, Barkley, Cross, \& Major (2014) further argue that cooperative learning is more suited for school and whereas collaborative learning is for colleges. This argument has some strength that more research on cooperative learning has been conducted at school levels. However, their argument that cooperative learning is conducted at school levels because it promotes close-ended tasks which are fit for school children and collaborative learning use open-ended tasks therefore it is suitable for college adult students is not entirely substantial. There are also many studies on cooperative learning which have been successfully conducted at higher education level. Although Barkley, Cross and Major (2014) make cooperative learning different from collaborative learning, they associate many of cooperative learning techniques to collaborative learning. It makes their argument paradoxical, and needs to be re-examined and re-investigated.

Practically in terms of planning and operating learning groups in higher education classrooms, most teachers will not be considerably concerned with the theoretical and semantic differences between cooperative and collaborative learning, rather they will adopt and adapt the degree of power and control where they feel comfortable and accomplish their goals (Brody \& Davidson, 1998). Barkley, Cross, \& Major (2014) argue that although cooperative and collaborative learning are differentiated in terms of their being structured and unstructured or as two different of methods for school and higher education respectively, substantial confusion sways in the literature of higher education over terminology. Some scholars today in the context of higher education use the term cooperative learning instead of collaborative learning (e.g., McCafferty, Jacobs, \& DaSilva Iddings, 2006; Johnson \& Johnson 2009). Students in cooperative learning settings are required to become responsible for their own and their group mates' learning. The existence of tests and quizzes ensures individual accountability because in these tests groups members do not help one another. Hence, although cooperative learning strategies require from group members to help one another, no peer in the group is supposed to hide or negatively depend on another. Proper grouping in cooperative learning guarantees that all groups encompass peers having different qualities so that the practice of problem-solving and social skills may be developed in all group peers (Millis, 2002).

The following table and figure (Table 1 and Figure 1) clearly sum up the argument. Both cooperative learning and collaborative learning are not exactly similar and have differences and are created for different contexts and situations for the ease of teachers and educators. Based on the argument, it may be concluded that cooperative learning may be more effective for the difficult circumstances where teachers have lack of equipment, have large classes, traditional teaching and learning environment with exam-based syllabus.

Table 1. Cooperative learning and collaborative learning

\begin{tabular}{lll}
\hline Cooperative learning & Collaborative learning \\
\hline 1. & Instructional & Non-instructional \\
2. & Very Structured & Not very structured \\
3. & Targeting one common goal & Without a common gaol \\
4. & Based on both closed and open-ended tasks & Based only on open-ended tasks \\
5. & Success of the group depends upon everyone pulling his or her & Students work together not necessarily for all members' \\
& weight & success \\
\hline
\end{tabular}




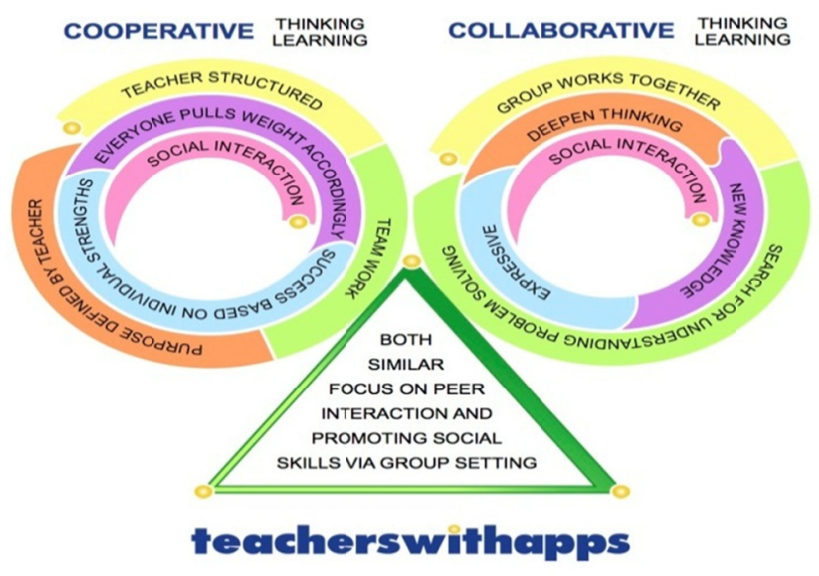

Figure 1. Cooperative learning versus collaborative learning: Clare (2015 www.teacherswithapps.com)

\section{Contextual Suitability of Cooperative Learning}

Since in the context of Pakistani higher education, classes are very large, we need an approach to group work that is very structured and, therefore, could address the management issues which are often pointed by teachers during the use of group work. We hypothesise that since group work and collaborative learning are not as structured as cooperative learning, these would not be useful to address the issue of class management and enhance student engagement in Pakistani context. We, therefore, argue that cooperative learning is a method that may address these issues in the ESL classes in the higher education institutes of Pakistan. Collaborative learning, on the one hand, is a form of team learning including small student-groups with assigned academic goals. These groups are mostly temporary that may be formed to improve students' critical thinking in-class discussion. Cooperative learning, on the other hand, is a careful and strategic team learning aiming at creating suitable, permanent teams of co-dependent peers assigned with a particular learning goal. The cooperative learning setting places great emphasis on student active participation in developing and improving their social skills. Since the results of cooperative learning are powerfully reliant on its being thoroughly structured, cooperative learning has happened to be most effectively well-defined and technically structured method of team learning (Cuseo, 1992).

\subsection{Empirical Evidence}

Empirical literature suggests that no study has tested cooperative learning in Pakistani ESL classes in higher education of Pakistan. However, there are some studies which have tested cooperative learning at the school level. For example, in the specific context of ESL/EFL teaching and learning in Asian culture, specifically in Pakistan, cooperative learning has been found to be very effective method for the improvement of students' academic achievement. For example, the empirical studies conducted in Pakistan so far provide evidence that the use of cooperative learning has been very effective when implemented after careful planning (Khan, 2008; 2011; Khan \& Ahmad 2014). The adoption of cooperative learning in Pakistani secondary schools enhanced students' academic achievement, reading and writing abilities (Khan, 2011; Khan \& Ahmad, 2014) and, especially, the low achievers benefitted from the cooperative setting in Pakistani schools (Khan, 2008).

Khan (2008) conducted an experimental study in a government school in Pakistan. The study aimed to investigate if cooperative learning improves eighth graders' academic performance in reading and writing in a compulsory English class. The treatment group was taught through a cooperative learning strategy, namely Student Team Achievement Division (STAD) and in the control class the whole-class teaching was used. The results of the post-test showed that the experimental group $(\mathrm{M}=72.83$ and $\mathrm{SD}=9.76)$ substantially performed better than the control group ( $\mathrm{M}=62.82$ and $\mathrm{SD}=10.99)$. Khan (2011), based on the data of his study Khan (2008), re-investigated if STAD improves low achievers' academic performance. The findings indicated that the low-achievers in the experimental group $(\mathrm{M}=50.13$ and $\mathrm{SD}=5.65)$ out-performed those in the control group $(\mathrm{M}=$ 64.19 and $\mathrm{SD}=6.52$ ). Khan \& Ahmad (2014) re-analysed the data of Khan (2008) to investigate the effects of cooperative learning on students' reading comprehension skills. The reading comprehension component of the pre- and post-test was composed of 50 items. The results indicated that experiment group $(\mathrm{M}=37.87)$ outperformed the control group $(\mathrm{M}=32.70)$. 


\section{Discussion and Conclusion}

Based on the above critical review and the empirical evidence, it may be argued that cooperative learning, thus, appears to be more suitable for Pakistani higher education classes. In collaborative learning, there is no guarantee that each group member will learn and be successful as a result of the process. On the other hand, the five elements of cooperative learning (if carefully used) are intended to ensure that every member learns in the group. The learning and understanding of each member is measured through quizzes or tests (Slavin, 1995). This is not possible in collaborative learning. The main aim of this paper is to suggest how to create cooperation among students. Since ESL classes in Pakistani public universities and colleges are very large and large number of students creates disturbances, the methods like collaborative learning which focuses on constructing social knowledge through dissent and competition might create chaotic situation. On the other hand, cooperative learning focuses on constructing social knowledge through cooperation in a structured environment tends to more effective to address the issues mentioned. Cooperative learning is structured and aims at having students mastered specific topics. Therefore, we deem it to be more effective contextually than collaborative learning because the curricula in Pakistani universities are very structured and exam-based and follow specific topics to be mastered. Moreover, in the context of Pakistani education system, language learning is examination-based; therefore, cooperative learning might serve the purpose better.

The most important purpose of using cooperative learning instead of collaborative learning in the context Pakistani higher education may be that students are new to such type of approaches and are mostly taught through traditional methods. Therefore, they might not take utmost responsibility of their learning and decision-making processes. We, therefore, assume that students may be made to start with cooperative learning in the context and then move to collaborative learning when they become experienced. Collaborative learning aims at enhancing free critical thinking with the goal to create new knowledge. In fact, it is unstructured. It aims to have group members reason about and solve conceptual problems that may have no explicit answers. Furthermore, in collaborative learning, all group members are not committed that each will learn and be successful as a result of the process (Olivares, 2005).

Specifically, in terms of ESL teaching and learning at higher education level in Pakistan, cooperative learning is arguably discussed to be very appropriate and effective. Since language learning needs the maximum engagement of students in the process of learning, cooperative learning, especially, in Pakistan seems to be more workable. As discussed earlier that the contextual issues such as large classes, the use of traditional method for teaching language and exam-based syllabi might create chaotic situations in ESL classes when other unstructured forms of group work i.e. collaborative learning would be used. Therefore, the discussion in this article recommends greater use of cooperative learning in universities and colleges of Pakistan.

\section{References}

Barkley, E. F., Cross, K. P., \& Major, C. H. (2014). Collaborative learning techniques: A handbook for college faculty. San Francisco, CA: Jossey-Bass John Wiley \& Sons Inc.

Brody, C. M. (1995). Collaborative or cooperative learning? Complementary practices for instructional reform. The Journal of Staff, Program, \& Organizational Development, 12(3), 134-143.

Brody, C. M., \& Davidson, N. (1998). Professional development for cooperative learning: Issues and approaches. New York: SUNY Press.

Bruffee, K. A. (1995). Sharing our toys: Cooperative learning versus collaborative learning. Change: The Magazine of Higher Learning, 27(1), 12-18. http://dx.doi.org/10.1080/00091383.1995.9937722

Bruffee, K. A. (1999). Collaborative learning: higher education, interdependence, and the authority of knowledge. North Charles Street, Baltimore: Johns Hopkins University Press.

Bughio, F. A. (2013). Improving English language teaching in large classes at university level in Pakistan. Ph.D, University of Sussex. Retrieved from http://sro.sussex.ac.uk/45170/

Clare, J. (2015). The Difference in Cooperative Learning \& Collaborative Learning [Blog post]. Retrieved from http://www.teacherswithapps.com/the-differences-in-cooperative-learning-collaborative-learning/

Cohen, E. G. (1994). Restructuring the classroom: Conditions for productive small groups. Review of educational research, 64(1), 1-35. http://dx.doi.org/10.3102/00346543064001001

Cooper, J. L., \& Robinson, P. (2002). The argument for making large classes seem small. New Directions for Teaching and Learning, 2000(81), 5-16. https://doi.org/10.1002/t1.8101

Cuseo, J. (1992). Cooperative learning vs. small-group discussions and group projects: The critical differences. 
Cooperative Learning and College Teaching, 2(3), 5-10.

Davidson, N. (1971). The small group-discovery method as applied in calculus instruction. The American Mathematical Monthly, 78(7), 789-791. https://doi.org/10.2307/2318022

Davidson, N., \& Major, C. H. (2014). Boundary crossings: Cooperative learning, collaborative learning, and problem-based learning. Journal on Excellence in College Teaching, 25(3\&4), 7-55. Retrieved from $\mathrm{http} / / /$ northweststate.edu/wp-content/uploads/files/BoundaryCrossings.pdf

Davidson, N., \& Worsham, T. (1992). Enhancing thinking through cooperative learning. New York, NY: Teachers College Press.

Fathman, A. K., \& Kessler, C. (1993). Cooperative language learning in school contexts. Annual Review of Applied Linguistics, 13, 127-140. https://doi.org/10.1017/S0267190500002439

Gillies, R. M. (2014). Developments in cooperative learning: Review of research. Annals of Psychology, 30(3), 792-801. http://dx.doi.org/10.6018/analesps.30.3.201191

Gillies, R. M., \& Boyle, M. (2008). Teachers' discourse during cooperative learning and their perceptions of this pedagogical practice. Teaching and Teacher Education, 24(5), 1333-1348. http://doi.org/10.1016/j.tate.2007.10.003

Johnson, D. W., \& Johnson, R. T. (1989). Cooperation and competition: Theory and research. Edina, MN: interaction Book Company.

Johnson, D. W., \& Johnson, R. T. (2009). An educational psychology success story: Social interdependence theory and cooperative learning. Educational Researcher, 38(5), 365-379. https://doi.org/10.3102/0013189X09339057

Kaufman, D., Sutow, E., \& Dunn, K. (1997). Three approaches to cooperative learning in higher education. Canadian Journal of Higher Education, 27(2/3), 37-66. Retrieved from http://ojs.library.ubc.ca/index.php/cjhe/article/download/183303/183261

Khan, S. A. (2008). An experimental study to evaluate the effectiveness of cooperative learning versus traditional learning method. PhD. International Islamic University, Islamabad.

Khan, S. A. (2011). The effect of cooperative learning on academic achievement of low achievers in English. Language in India, 11(3), 232-242.

Khan, S. A., \& Ahmad, R. N. (2014). Evaluation of the effectiveness of cooperative learning method versus traditional learning method on the reading comprehension of the students. Journal of Research and Reflections in Education (JRRE), 8(1), 55-64.

Laal, M., \& Laal, M. (2012). Collaborative learning: what is it?. Procedia-Social and Behavioral Sciences, 31, 491-495. https://doi.org/10.1016/j.sbspro.2011.12.092

Mansoor, S. (2003). Language Planning in Higher Education: Issues of Access and Equity. Lahore School of Economics Journals, 8(2), 17-42. http://121.52.153.178:8080/xmlui/handle/123456789/5580

Matthews, M. (1992). Gifted Students talk about cooperative learning. Educational Leadership, 50(2), 48-50.

McCafferty, S. G., Jacobs, G. M., \& Iddings, A. C. D. (Eds.) (2006). Cooperative learning and second language teaching. Cambridge: Cambridge University Press.

Millis, B. J. (2002). Enhancing learning and more! Through Cooperative Learning. IDEA paper, 38, 1-6. Kansas State Univ., Manhattan. IDEA Center.

Olivares, O. J. (2005). Collaborative critical thinking: Conceptualizing and defining a new construct from known constructs. Issues in Educational Research, 15(1), 86-100. Retrieved from http://www.iier.org.au/iier15/olivares.html

Rahman, T. (1999). The language of employment: The case of Pakistan. Research Report Series \# 23. Islamabad: The Sustainable Development Policy Institute.

Rassool, N., \& Mansoor, S. (2009). Contemporary issues in language, education and development in Pakistan. In N. Rasool (Ed.), Global Issues in Language, Education and Development: Perspectives from Post-colonial Countries. New Delhi: Orient Longman.

Rockwood, H. S. (1995). Collaborative learning an Approach of learning. National teaching and Learning Forum, $4(6), 1-15$. 
Rockwood, H. S. (1995). Cooperative and collaborative learning. The national teaching \& learning forum, 4(6), $8-9$.

Romney, J. C. (1996). The benefits of collaborative learning. New Currents, 3(6). http://www.ucalgary.ca/pubs/Newsletters/Currents/Vol3.6/Benefits.html

Romney, J. C. (1997). Collaborative learning in a translation course. Canadian Modern Language Review, 54(1), 48-67. http://dx.doi.org/10.3138/cmlr.54.1.48

Shamim, F. (1993). Teacher-learner behaviour and classroom processes in large ESL classes in Pakistan. Ph.D, University of Leeds, UK. Retrieved from http://core.kmi.open.ac.uk/download/pdf/43718.pdf

Shamim, F. (2011). English as the language for development in Pakistan: Issues, challenges and possible solutions. In H. Coleman (Ed., 2001), Dreams and Realities: Developing Countries and the English Language (pp. 291-311). London: British Council.

Slavin, R. E. (1995). Cooperative learning: theory, research, and practice (2nd ed.) Boston: Allyn and Bacon.

Warsi, J. (2004). Conditions under which English is taught in Pakistan: An applied linguistic perspective. Sarid Journal, 1(1), 1-9. Retrieved from http://sarid.net/sarid-journal/2004_Warsi.pdf

\section{Copyrights}

Copyright for this article is retained by the author(s), with first publication rights granted to the journal.

This is an open-access article distributed under the terms and conditions of the Creative Commons Attribution license (http://creativecommons.org/licenses/by/4.0/). 